\title{
Performance and metabolic responses of Holstein calves to supplemental chromium in colostrum and milk
}

\author{
A. Ghorbani, ${ }^{*}$ H. Sadri,,${ }^{1}$ A. R. Alizadeh, ${ }^{*}$ and R. M. Bruckmaier‡ \\ *Department of Animal Science, Saveh Branch, Islamic Azad University, Saveh, Iran \\ †Department of Clinical Science, Faculty of Veterinary Medicine, University of Tabriz, Tabriz 51666-17766, Iran \\ $\ddagger$ Veterinary Physiology, Vetsuisse Faculty, University of Bern, Bremgartenstr. 109a, CH-3001 Bern, Switzerland
}

\section{ABSTRACT}

Twenty-two newborn Holstein female calves $(\mathrm{BW}=$ $39.7 \pm 0.40 \mathrm{~kg}$ ) were used to investigate the effects of chromium-L-methionine (Cr-Met) supplementation of colostrum for $3 \mathrm{~d}$ after birth and mature milk up to wk 8 on feed intake, growth performance, health status, and metabolic and endocrine traits. Calves were randomly assigned to 2 groups, each consisting of 11 animals: 1) control and 2) $0.03 \mathrm{mg}$ of supplemental $\mathrm{Cr} / \mathrm{kg}$ of $\mathrm{BW}^{0.75}$. Body weight, height at withers, and hearth girth were measured weekly. Dry matter intake, rectal temperature, fecal score, and respiratory score were recorded daily. Blood samples were collected at 12, 24, and $72 \mathrm{~h}$ after birth, and then every week up to 8 wk. Chromium did not affect mean body weight, dry matter intake, and withers height, but it increased hearth girth and average daily gain, tended to increase final $\mathrm{BW}$, and decreased feed conversion ratio. Respiration rate increased and fecal score decreased with $\mathrm{Cr}$, and rectal temperature tended to decrease with $\mathrm{Cr}$. No $\mathrm{Cr} \times$ time interactions were observed for performance and health status results except for fecal score. Blood glucose, insulin, insulin-to-glucose ratio, insulin-like growth factor-I, total protein, and triiodothyronine were not affected, whereas blood $\beta$-hydroxybutyrate, nonesterified fatty acids, cholesterol, cortisol, and thyroxin were affected by Cr supplementation. Supplemental Cr-Met decreased blood $\beta$-hydroxybutyrate at $72 \mathrm{~h}$ and in wk $1,3,4,5$, and 6 and decreased blood nonesterified fatty acids at $12 \mathrm{~h}$ and in wk 3, 4, and 5 after birth. Blood cholesterol decreased in all sampling times, except for $12 \mathrm{~h}$ and wk 7. Chromium decreased blood cortisol at $24 \mathrm{~h}$ and in wk 2, 4, and 8. In conclusion, the present results demonstrate the beneficial effects of colostrum and milk supplementation with $\mathrm{Cr}$ to improve the performance and metabolic status of newborn calves.

Key words: chromium, dairy calf, performance, physiology

Received March 3, 2012.

Accepted June 11, 2012

${ }^{1}$ Corresponding author: sadri@tabrizu.ac.ir

\section{INTRODUCTION}

It is increasingly believed not only that colostrum is a source of $\operatorname{IgG}$ and nutrients, but also that it contains a tremendous number of biologically active compounds, such as insulin, IGF, and growth hormone (Blum and Hammon, 2000; Blum, 2006; Penchev Georgiev, 2008). It is interesting that in many cases, the amounts of these compounds are much higher in colostrum than in blood. It has been shown in calves that several of the ingested hormones and growth factors (such as insulin and IGF) have specific receptors localized in the mucosa of the small intestine and colon. The receptors are influenced by early postnatal nutrition, which will probably affect gastrointestinal tract (GIT) development upon receptor interaction (Blum, 2006).

On the other hand, $\mathrm{Cr}$ is biologically active as part of a biomolecule called chromodulin, which is part of an insulin-signaling pathway (Davis and Vincent, 1997; Davis et al., 1997). Chromodulin stimulates the tyrosine kinase activity of insulin-activated insulin receptor (Davis and Vincent, 1997; Davis et al., 1997) and membrane phosphotyrosine phosphatase in adipocytes membranes. Additionally, the IGF-I receptor belongs to a family of receptor proteins that includes insulin receptor, suggesting that chromodulin may activate the tyrosine kinase activity of IGF-I receptor as well (Heldin, 1995). It has been shown that $\mathrm{Cr}$ in the organic form is more efficiently absorbed than $\mathrm{Cr}$ in inorganic form (Anderson, 1995). Previous studies using the intravenous glucose tolerance test or the insulin challenge test showed that $\mathrm{Cr}$ in the organic form increased glucose disappearance rate and decreased area under the curve for plasma glucose in calves (Bunting et al., 2000; Kegley et al., 2000) and dairy cows (Subiyatno et al., 1996; Hayirli et al., 2001). Chromium requirements of cattle have not been estimated by the NRC (2001). It was traditionally assumed that the practical diets fed to domestic animals provide sufficient $\mathrm{Cr}$ to meet animal requirements (Lloyd et al., 2010). However, in recent years, several studies in cattle have indicated beneficial effects of $\mathrm{Cr}$ supplementation on physiological and production responses, especially during periods 
of increased stress, such as transportation (MoonsieShageer and Mowat, 1993; Mowat et al., 1993), the transition from gestation to lactation in cattle (Smith et al., 2005; Sadri et al., 2009; Sadri et al., 2012), and high ambient temperatures (Yari et al., 2010).

Feeding colostrum and the intake of nutrient and nonnutrient components during the postnatal period is associated with important transient and long-lasting systemic effects on the nutritional status, on metabolism, and on various endocrine systems (Blum, 2006). Little is known regarding the effects of $\mathrm{Cr}$ supplementation of the dam's diet on $\mathrm{Cr}$ concentrations in milk. Recently, Lloyd et al. (2010) reported that supplementation of the dam's diet with $\mathrm{Cr}$ propionate at a level of $2 \mathrm{mg}$ of $\mathrm{Cr} / \mathrm{kg}$ of DM of the dam's diet (at 4 times the permitted level) did not increase $\mathrm{Cr}$ concentrations in milk, in agreement with previously reported studies in cattle (Hayirli et al., 2001) and humans (Kumpulainen et al., 1980). It thus appears that supplementing calves with the essential nutrients added to colostrum or milk is a means of providing these important components to the neonate during the stressful postnatal period. Recently, Yari et al. (2010) investigated pre- and postweaning calf physiological responses to increased $\mathrm{Cr}$ supply from $\mathrm{d}$ 4 of age under high ambient temperatures. However, to our knowledge, the question of whether supplementing colostrum with $\mathrm{Cr}$ affects growth performance, health status, and metabolic indicators in calves has not been addressed.

The current study was designed to determine whether chromium-L-methionine (Cr-Met) supplementation of colostrum for $3 \mathrm{~d}$ after birth and mature milk up to wk 8 influences feed intake, growth performance, health status, and metabolic and endocrine traits in Holstein calves.

\section{MATERIALS AND METHODS}

\section{Experimental Design, Calves, and Treatment}

Twenty-two newborn Holstein female calves (BW = $39.7 \pm 0.40 \mathrm{~kg}$; mean $\pm \mathrm{SE}$ ), born at the calf-raising facilities of Sharifabad Dairy Facilities (Qazvin, Iran), were studied in a completely randomized design. They were separated from their dams at birth and were transferred to individual hutches $(2.7 \times 1.2 \times 1.6 \mathrm{~m})$ bedded with clean wheat straw until 8 wk of age. The individual hutches had a roofed area $(1.2 \times 2.1 \mathrm{~m})$ to protect the calf from direct sunlight and rainfall and had a rear window $(0.50 \times 0.50 \mathrm{~m})$. Calves were randomly assigned to 2 groups, a control (CTR) group and a supplemental Cr (CRM) group, each consisting of 11 animals. Chromium was added as a Cr-Met
Table 1. Chemical composition of milk

\begin{tabular}{lcl}
\hline Item, $\%$ & Mean & SEM \\
\hline TS & 12.9 & 0.01 \\
Fat & 3.61 & 0.04 \\
Protein & 3.52 & 0.005 \\
Lactose & 4.87 & 0.007 \\
\hline
\end{tabular}

supplement [MicroPlex 1000, supplies 1,000 mg/kg of $\mathrm{Cr}$ as Cr-Met $(10 \% \mathrm{Cr}$ and $90 \%$ Met, wt/wt); Zinpro, Inc., Eden Prairie, MN, provided by Yasna Mehr Co., Tehran, Iran] to colostrum for $3 \mathrm{~d}$ after birth and whole milk up to wk 8 to supply $0.03 \mathrm{mg}$ of supplemental $\mathrm{Cr} / \mathrm{kg}$ of $\mathrm{BW}^{0.75}$. The Cr-Met supplementation was adjusted based on BW of the calves at the end of every week for the following week of the experimental period. Because $\mathrm{Cr}$ requirements of dairy calves are not known (NRC, 2001), the present dosage of $\mathrm{Cr}$ was chosen based on previous literature (Yari et al., 2010). Calves received pooled colostrum at 10\% of BW 2 times daily for $3 \mathrm{~d}$ and whole milk from d 4 until weaning. Calves received $2 \mathrm{~L}$ of whole milk (Table 1 ) twice daily at 0600 and $1400 \mathrm{~h}$, with ad libitum access to a pelleted starter concentrate (Table 2) from d 5 and fresh water. From 6 wk of age, calves were offered chopped alfalfa hay. Amounts of starter concentrate and hay offered and orts were recorded daily for individual calves, and daily feed intake was determined. The calves used in the study were weaned at 3 mo of age; however, the study covered the period from birth through wk 8 after birth.

The starter concentrate was sampled weekly. The samples were dried at $55^{\circ} \mathrm{C}$ for $48 \mathrm{~h}$, ground using a Wiley mill to pass a 1-mm screen (Wiley Laboratory Pulverizer, Ogaw Seiki Co. Ltd., Tokyo, Japan), and stored at $-20^{\circ} \mathrm{C}$ until analyses. The feed samples were analyzed for CP (method 984.13; AOAC International, 2002), ADF (method 973.18; AOAC International, 2002), ether extract, and ash (Table 2). Body weight, withers height, and heart girth were measured at birth and every week during the course of the study.

\section{Rectal Temperature, Respiration Rate, and Fecal Consistency}

Rectal temperature was recorded at $1100 \mathrm{~h}$ each day during the experiment period with a thermometer (Qingdao Dacon Trading Co. Ltd., Shandong, China) held in the rectum of the calf for $1 \mathrm{~min}$. Fecal consistency was scored daily on a scale of 1 to 4 , with 1 being firm, 2 being slightly loose, 3 being loose, and 4 being watery in consistency (Larson et al., 1977). Respiration rate was measured at 0900 and $1400 \mathrm{~h}$ daily, by visual observation, for 3 separate minutes. 
Table 2. Ingredient and nutrient composition (DM basis) of the calf starter

\begin{tabular}{lc}
\hline Item, \% unless noted & Value \\
\hline Ingredient & \\
Coarsely ground corn & 34.8 \\
Coarsely ground barley & 19.6 \\
Soybean meal & 35.2 \\
Alfalfa meal & 2.0 \\
Wheat bran & 5.0 \\
Vitamin and mineral mix ${ }^{1}$ & 0.5 \\
Dicalcium phosphate & 1.5 \\
Sodium bicarbonate & 1.0 \\
NaCl & 0.4 \\
Chemical composition & \\
ME, ${ }^{2}$ Mcal/kg & 2.95 \\
DM & 92.2 \\
CP & 20.4 \\
ADF & 8.00 \\
Ether extract & 3.10 \\
Ash & 5.62 \\
\hline
\end{tabular}

${ }^{1}$ Contained the following per kilogram of supplement: $250,000 \mathrm{IU}$ of vitamin A, 50,000 IU of vitamin D, 1,500 IU of vitamin E, 2.25 g of manganese, $120 \mathrm{~g}$ of $\mathrm{Ca}, 7.7 \mathrm{~g}$ of $\mathrm{Zn}, 20 \mathrm{~g}$ of P, $20.5 \mathrm{~g}$ of $\mathrm{Mg}, 186 \mathrm{~g}$ of $\mathrm{Na}, 1.25 \mathrm{~g}$ of Fe, $3 \mathrm{~g}$ of S, $14 \mathrm{mg}$ of $\mathrm{Co}, 1.25 \mathrm{~g}$ of $\mathrm{Cu}, 56 \mathrm{mg}$ of I, and $10 \mathrm{mg}$ of Se.

${ }^{2}$ Calculated according to NRC (2001).

\section{Blood Sampling and Analysis}

Blood samples were taken from the jugular vein using Vacutainer tubes (Shandong Weigao Group Medical Polymer Co. Ltd., Weihei, Shandong, China) at 12, 24 , and $72 \mathrm{~h}$ after birth, and then every week up to 8 wk. All tubes were immediately placed in wet ice and within $1 \mathrm{~h}$ were centrifuged at $4^{\circ} \mathrm{C}$ at $1,850 \times g$ for 20 min. The serum was obtained and frozen $\left(-20^{\circ} \mathrm{C}\right)$ until analyses. Serum total protein (TP), glucose, and cholesterol were determined using commercially available kits (Pars Azmun Co., Tehran, Iran). Concentrations of cortisol, thyroxin $\left(\mathbf{T}_{4}\right)$, and triiodothyronine $\left(\mathbf{T}_{3}\right)$ were measured using ELISA with commercial kits (Diaplus Inc., North York, ON, Canada). The concentrations of NEFA and BHBA were measured using commercial kits with a Technicon-RA 1000 Autoanalyzer (DRG Co., Marburg, Germany). Serum insulin and IGF-I concentrations were determined by RIA, according to the methods described by Vicari et al. (2008).

\section{Statistical Analysis}

The data were analyzed using the MIXED procedure of SAS Institute (2003), using repeated measures with a first-order autoregressive covariance structure in time. The model included the effects of treatment, time (day or week), and the interaction of treatment and time. Birth weight was included in the statistical model as a covariate for analysis of covariance applied to their corresponding measurements during the experimental period. The Bonferroni correction method was used for correction of multiple comparisons. Results are presented as least squares means and standard errors of the means. A threshold of significance was set at $P \leq$ 0.05 ; trends were declared at $0.05<P \leq 0.10$.

\section{RESULTS}

\section{Performance, Rectal Temperature, Fecal Consistency, and Respiration Rate}

Birth weight of calves in the CRM group was 39.8 $\pm 0.32 \mathrm{~kg}$ (mean $\pm \mathrm{SE}$ ) and that of calves in the CTR group was $39.7 \pm 0.57 \mathrm{~kg}$ (mean $\pm \mathrm{SE}$ ). Table 3 shows the effects of Cr-Met supplementation on growth performance, feed intake, and health status. Mean BW, DMI, and withers height were not significantly affected by $\mathrm{Cr}$ supplementation. A trend $(P=0.10)$ for final BW to increase was observed with Cr-Met supplementation. Heart girth in the CRM group was greater $(P$ $<0.05)$ than that in the CTR group. Calves in the CRM group had greater $(P<0.05)$ ADG than did those in the CTR group. Feed conversion ratio (FCR) was lower $(P<0.05)$ for calves in the CRM group than for those in the CTR group.

A trend $(P=0.07)$ was observed for rectal temperature to decrease with Cr-Met supplementation. Fecal score was lower $(P<0.05)$ and respiration rate was greater $(P<0.05)$ in the CRM group compared with the CTR group.

Performance and health status results were all affected by time. No $\mathrm{Cr} \times$ time interactions were observed for performance and health status results except for withers height $(P<0.05)$, hearth girth, and fecal score $(P=0.08)$.

\section{Blood Metabolites and Hormones}

The effects of Cr-Met supplementation on glucose, insulin, insulin-to-glucose ratio, IGF-I, TP, $\mathrm{T}_{3}$, and $\mathrm{T}_{3}: \mathrm{T}_{4}$ from $12 \mathrm{~h}$ after birth through wk 8 are presented in Table 4. Blood concentrations of glucose, insulin, insulin-to-glucose ratio, IGF-I, TP, and $\mathrm{T}_{3}$ were not affected by treatment. Chromium supplementation affected blood concentrations of $\mathrm{T}_{4}$ and $\mathrm{T}_{3}: \mathrm{T}_{4}$ ratio $(P<$ 0.05). Blood glucose, insulin, insulin-to-glucose ratio, IGF-I, $\mathrm{T}_{3}$, and $\mathrm{T}_{3}: \mathrm{T}_{4}$ ratio were affected by sampling time. A significant treatment $\times$ time effect was observed for blood $\mathrm{T}_{4}(P \leq 0.05)$, which was decreased for calves in the CRM group compared with those in the CTR group at 12 and $72 \mathrm{~h}$ after birth and in wk 4 and 6. In addition, at $72 \mathrm{~h}$ and in wk 4 and 6 , calves in the CRM group had a greater $(P \leq 0.05)$ blood $\mathrm{T}_{3}: \mathrm{T}_{4}$ ratio than did calves in the CTR group (Table 4 ). 
Table 3. Effects of Cr supplementation on the performance and health status of Holstein calves ${ }^{1}$

\begin{tabular}{|c|c|c|c|c|c|c|}
\hline \multirow[b]{2}{*}{ Item } & \multicolumn{2}{|c|}{ Treatment $(\mathrm{T})^{2}$} & \multirow[b]{2}{*}{ SEM } & \multicolumn{3}{|c|}{$P$-value } \\
\hline & CTR & CRM & & $\mathrm{T}$ & Time & $\mathrm{T} \times$ time \\
\hline Mean BW, kg & 50.9 & 52.3 & 0.83 & 0.22 & $<0.01$ & 0.40 \\
\hline Final BW, kg & 65.8 & 69.3 & 1.47 & 0.10 & - & - \\
\hline $\mathrm{ADG}, \mathrm{kg} / \mathrm{d}$ & 0.54 & 0.66 & 0.04 & 0.04 & $<0.01$ & 0.16 \\
\hline Starter intake, $\mathrm{kg} / \mathrm{d}$ & 0.51 & 0.53 & 0.04 & 0.83 & $<0.01$ & 0.99 \\
\hline Total DMI, kg/d & 0.98 & 0.99 & 0.04 & 0.83 & $<0.01$ & 0.99 \\
\hline FCR & 2.23 & 1.79 & 0.11 & 0.008 & $<0.01$ & 0.99 \\
\hline Heart girth, $\mathrm{cm}$ & 83.2 & 84.8 & 0.38 & 0.009 & $<0.01$ & 0.08 \\
\hline Withers height, $\mathrm{cm}$ & 60.8 & 61.4 & 0.24 & 0.11 & $<0.01$ & 0.04 \\
\hline Rectal temperature, ${ }^{\circ} \mathrm{C}$ & 38.9 & 38.8 & 0.02 & 0.07 & $<0.01$ & 0.21 \\
\hline Fecal score & 2.17 & 2.10 & 0.02 & 0.02 & $<0.01$ & 0.08 \\
\hline Respiration rate, $\min ^{-1}$ & 31.1 & 34.3 & 0.94 & 0.02 & $<0.01$ & 0.74 \\
\hline
\end{tabular}

${ }^{1} \mathrm{FCR}=$ feed conversion ratio [milk DMI + starter intake + hay intake] $(\mathrm{kg} / \mathrm{d}) / \mathrm{ADG}(\mathrm{kg} / \mathrm{d})$.

${ }^{2}$ Treatments: $\mathrm{CTR}=$ control; $\mathrm{CRM}=$ with supplemental $\mathrm{Cr}, 0.03 \mathrm{mg} / \mathrm{kg}$ of $\mathrm{BW}^{0.75}$.

Figures 1, 2, 3, and 4 show blood concentrations of supplementation $(P<0.05)$. Blood BHBA, NEFA, and BHBA, NEFA, cholesterol, and cortisol from $12 \mathrm{~h}$ af- cholesterol were affected by sampling time $(P<0.05)$. ter birth until wk 8, all of which were affected by $\mathrm{Cr}$ Blood BHBA concentrations decreased $(P<0.05)$ in

Table 4. Effects of Cr supplementation on serum metabolites and hormones from $12 \mathrm{~h}$ after birth through wk 8 in Holstein calves ${ }^{1}$

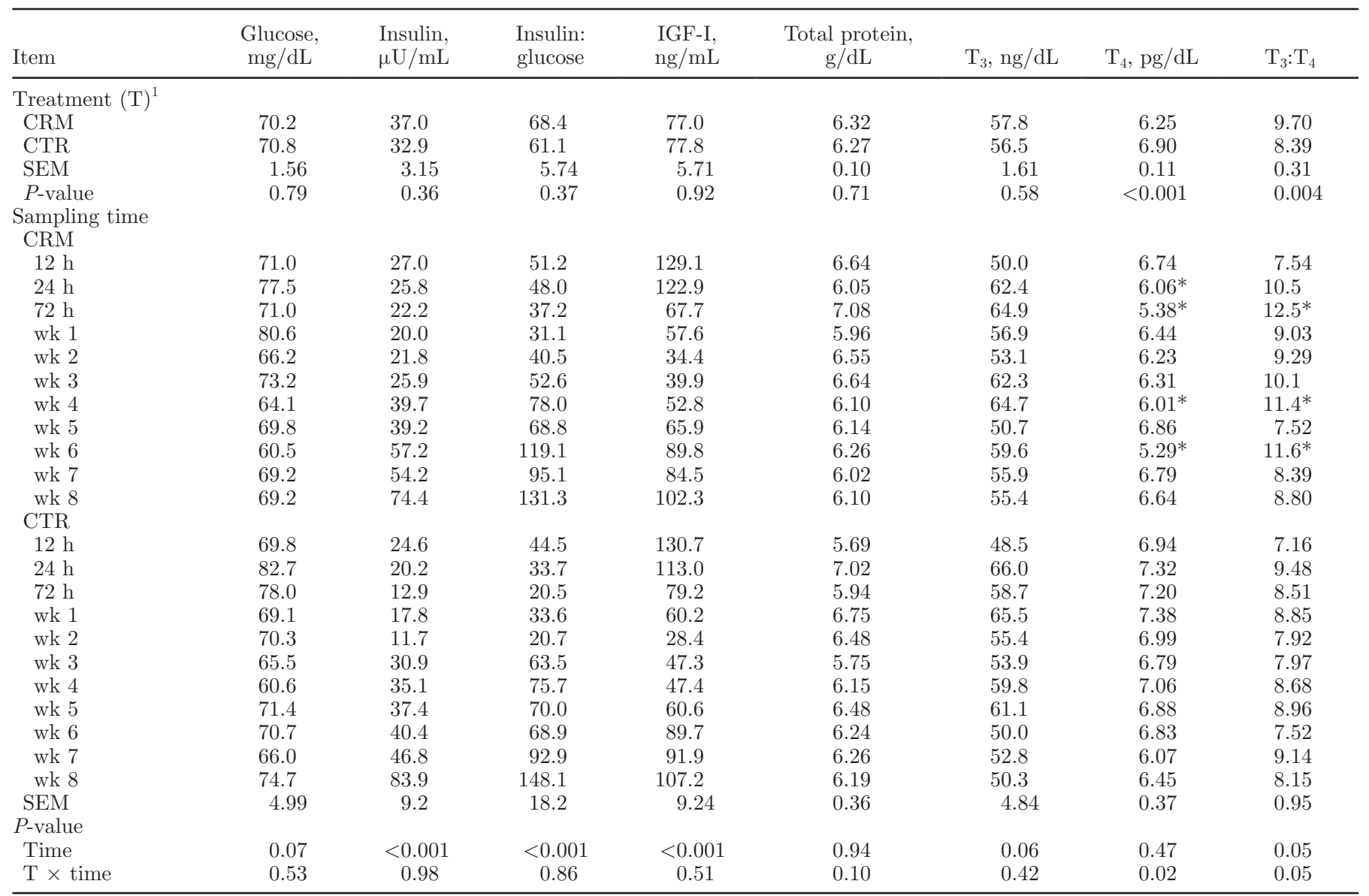

${ }^{1}$ Treatments $(\mathrm{T}): \mathrm{CTR}=$ control, $\mathrm{CRM}=$ with supplemental $\mathrm{Cr}, 0.03 \mathrm{mg} / \mathrm{kg}$ of $\mathrm{BW}^{0.75}$.

${ }^{2} \mathrm{~T}_{3}=$ triiodothyronine; $\mathrm{T}_{4}=$ thyroxin.

${ }^{*} P<0.05$, significant difference between CRM and CTR at a given time point. 


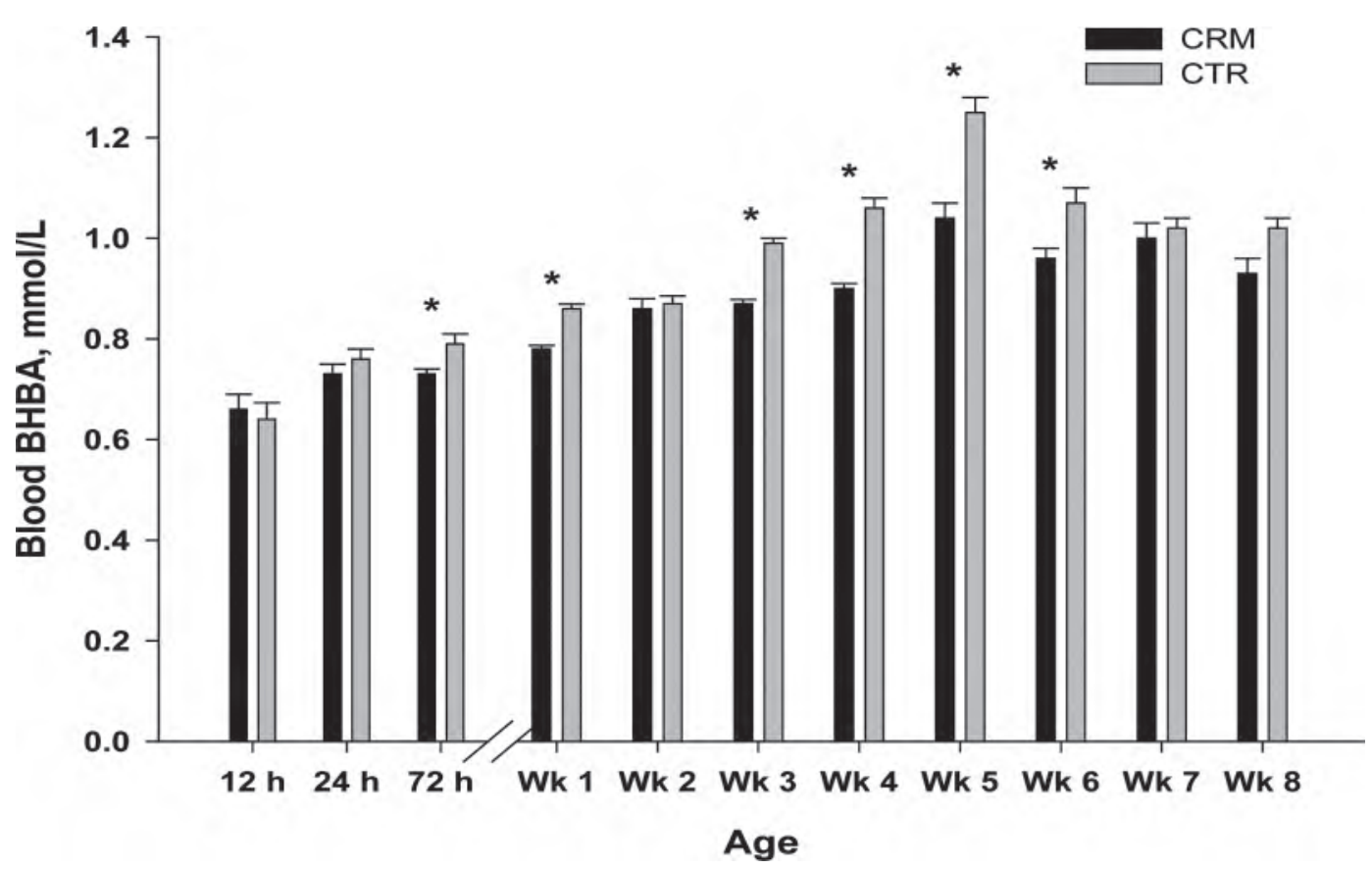

Figure 1. Blood concentrations of BHBA (means $\pm \mathrm{SEM}, \mathrm{mmol} / \mathrm{L}$ ) in Holstein calves fed either no $(\mathrm{CTR})$ or $0.03 \mathrm{mg} / \mathrm{kg}$ of BW $\mathrm{BW}^{0.75}$ of supplemental $\mathrm{Cr}(\mathrm{CRM})$ from $12 \mathrm{~h}$ after birth until wk 8. An asterisk $(*)$ indicates a significant difference $(P<0.05)$ between CRM and CTR at a given time point. Treatment effect, $P<0.001$; time effect, $P<0.001$; treatment $\times$ time effect, $P<0.001$.

calves supplemented with Cr-Met at $72 \mathrm{~h}$ after birth and in wh 1, 3, 4, 5, and 6 (Figure 1). Calves in the CRM group had lower $(P<0.0 .5)$ concentrations of NEFA than did calves in the CTR group at $12 \mathrm{~h}$ after birth and in wk 3, 4, and 5 (Figure 2). Blood cholesterol concentrations were lower $(P<0.05)$ for calves in the CRM group than for those in the CTR group at all sampling times, with the exception of $12 \mathrm{~h}$ and wk 7 (Figure 3). At $24 \mathrm{~h}$ after birth and in wk 2, 4, and 8, calves in the CRM group had lower $(P<0.05)$ blood cortisol concentrations than did calves in the CTR group (Figure 4).

\section{DISCUSSION}

Chromium supplementation did not affect mean BW; however, as expected, BW was affected by time and increased as calves approached 8 wk of age. This result is in agreement with previously reported results in calves supplemented with $\mathrm{Cr}$ under normal conditions (Depew et al., 1998; Bunting et al., 2000) and at high ambient temperatures (Yari et al., 2010). Total DMI was not affected by treatment; however, calves in the CRM group had greater ADG than did calves in the CTR group, suggesting a more efficient tissue accretion in calves supplemented with Cr. This was supported by the lower FCR and the tendency for a higher final BW in the CRM treatment compared with the CTR treatment. Studies regarding the effect of $\mathrm{Cr}$ supplementation on growth performance in calves has yielded ambiguous results. Moonsie-Shageer and Mowat (1993) and Kegley et al. (1997) reported a positive effect of $\mathrm{Cr}$ supplementation on BW gain, whereas others (Mathison and Engstrom, 1995; Swanson et al., 2000; Yari et al., 2010) did not observe this response. Yari et al. (2010) reported no effects of $\mathrm{Cr}$ supplementation on preweaning and postweaning ADG and FCR, and they concluded that increased dietary $\mathrm{Cr}$ may have only minor effects on calf growth. Our observations in the present study are not in agreement because we observed significant effects of $\mathrm{Cr}$ supplementation on ADG and FCR, as well as a tendency for increased final BW. We supplemented calves with Cr-Met added to colostrum from birth until d 3 of age and then mature milk up to wk 8, but in the previous study by Yari et al. (2010), calves were supplemented with Cr-Met from d 4 of age. Therefore, we could assume that the improved ADG, FCR, and final $\mathrm{BW}$ with $\mathrm{Cr}$ in the present study were influenced in part by $\mathrm{Cr}$ supplementation of colostrum because intake of nutrient and nonnutrient components during the postnatal period is associated with important transient and long-lasting systemic effects on the nutritional status, on metabolism, and on various endocrine systems (Blum, 2006).

Calves in this study were generally healthy, with no mortality during the study. Rectal temperature was in 


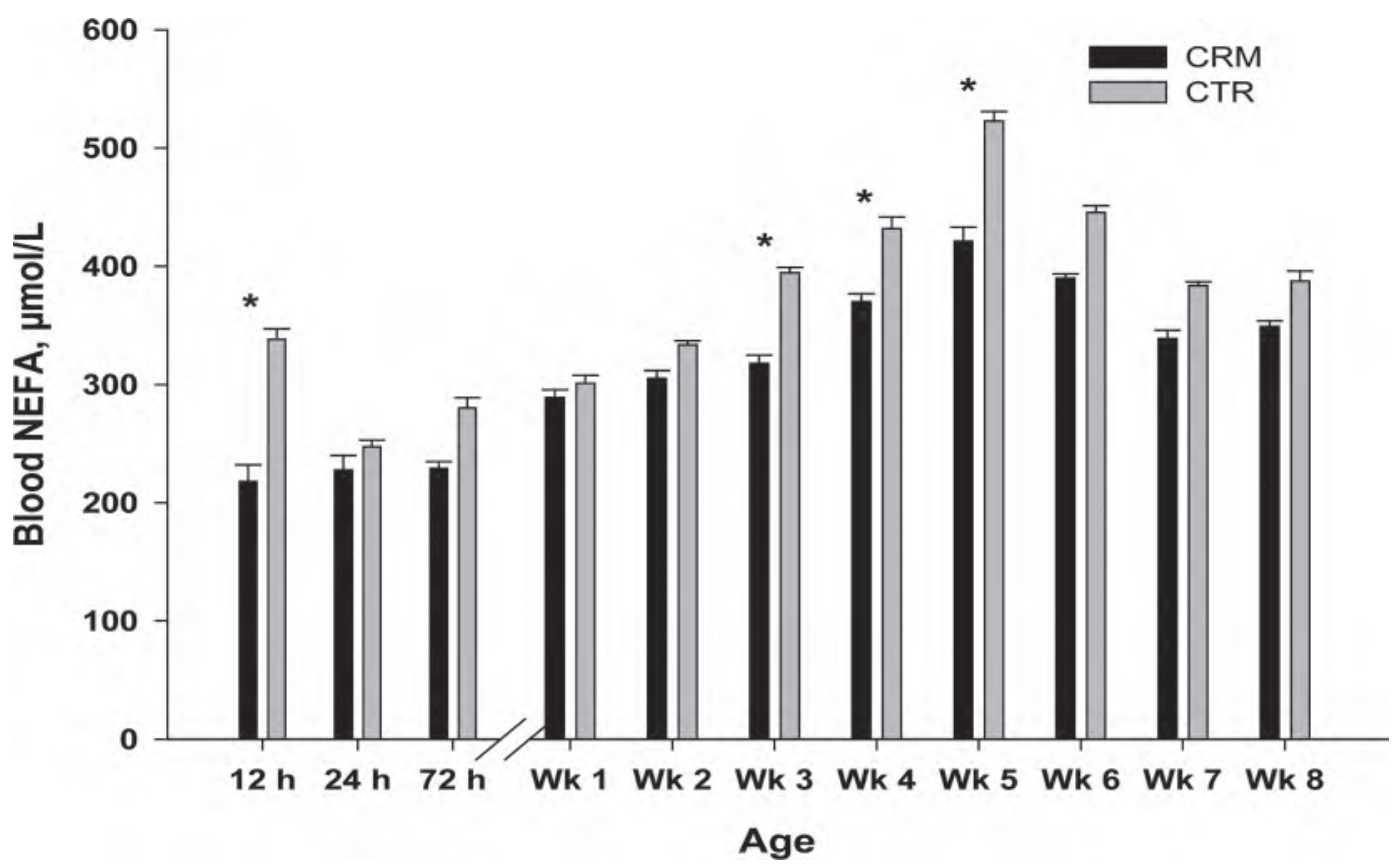

Figure 2. Blood concentrations of NEFA (means \pm SEM, $\mu \mathrm{mol} / \mathrm{L}$ ) in Holstein calves fed either no (CTR) or $0.03 \mathrm{mg} / \mathrm{kg}$ of BW $\mathrm{BW}^{0.75}$ of supplemental $\mathrm{Cr}(\mathrm{CRM})$ from $12 \mathrm{~h}$ after birth until wk 8 . An asterisk $(*)$ indicates a significant difference $(P<0.05)$ between CRM and CTR at a given time point. Treatment effect, $P<0.001$; time effect, $P<0.001$; treatment $\times$ time effect, $P=0.35$.

the normal range; however, calves in the CRM group had slightly lower rectal temperatures compared with those in the CTR group, implying a greater ability in supplemented calves to cope with environmental conditions. The lower fecal score and the higher respiration rate for calves in the CRM group than for those in the

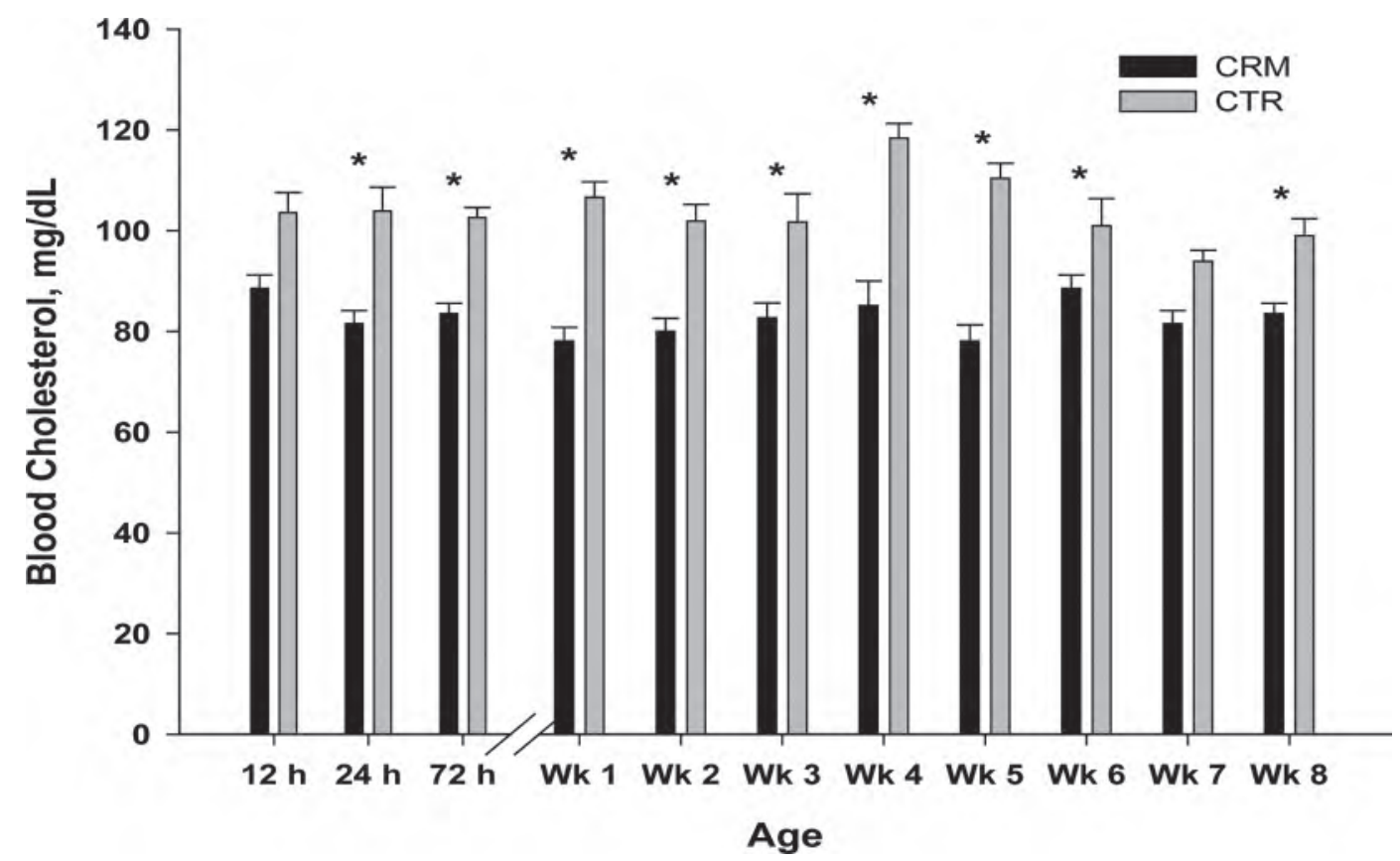

Figure 3. Blood concentrations of cholesterol (means $\pm \mathrm{SEM}, \mathrm{mg} / \mathrm{dL}$ ) in Holstein calves fed either no $(\mathrm{CTR})$ or $0.03 \mathrm{mg} / \mathrm{kg}$ of $\mathrm{BW}^{0.75}$ of supplemental $\mathrm{Cr}(\mathrm{CRM})$ from $12 \mathrm{~h}$ after birth until wk 8 . An asterisk $(*)$ indicates a significant difference $(P<0.05)$ between CRM and CTR at a given time point. Treatment effect, $P<0.001$; time effect, $P<0.01$; treatment $\times$ time effect, $P<0.001$. 


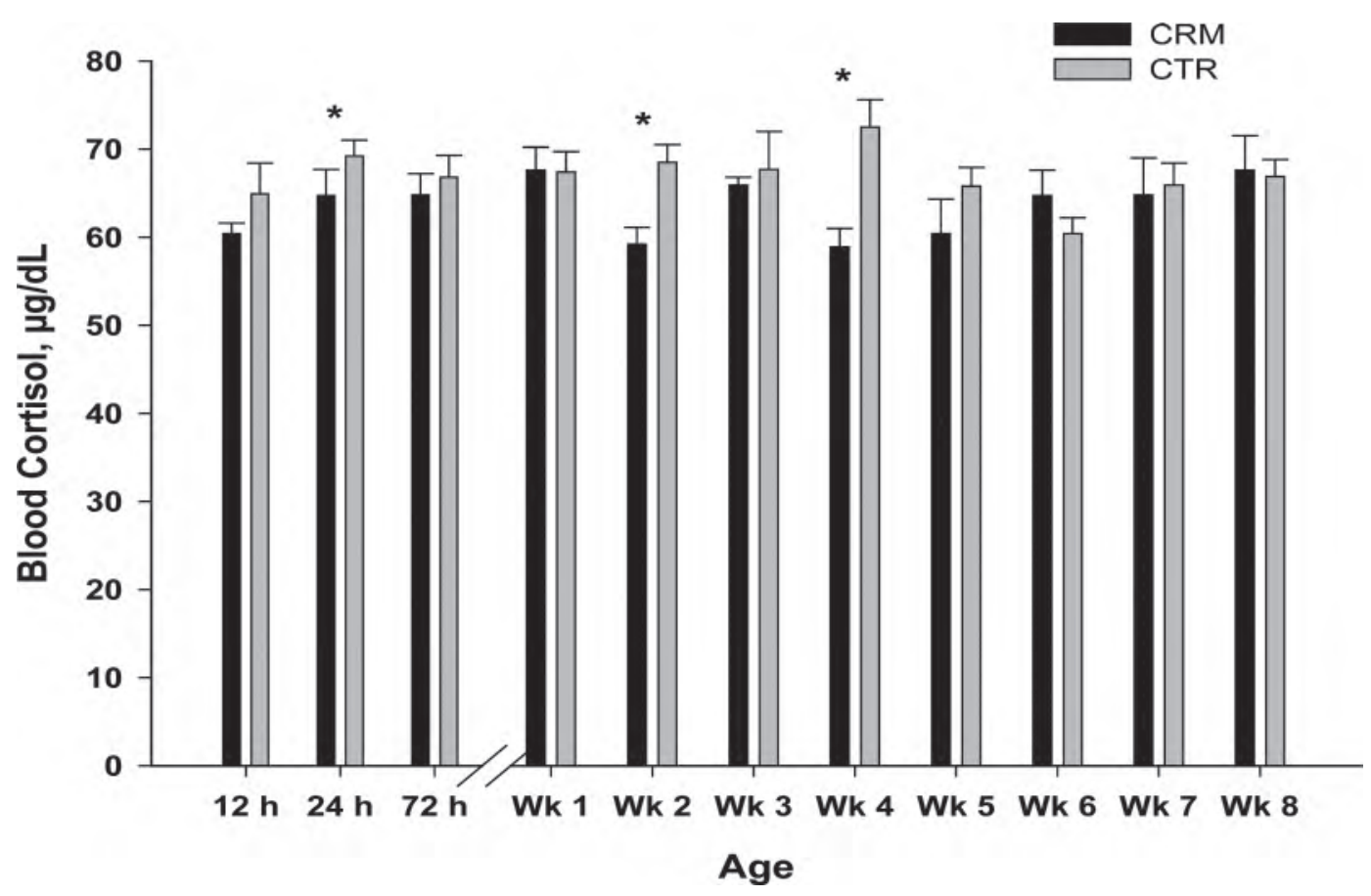

Figure 4. Blood concentrations of cortisol (means $\pm \mathrm{SEM}, \mu \mathrm{g} / \mathrm{dL}$ ) in Holstein calves fed either no (CTR) or $0.03 \mathrm{mg} / \mathrm{kg}^{\circ}$ of BW $\mathrm{W}^{0.75}$ of supplemental $\mathrm{Cr}(\mathrm{CRM})$ from $12 \mathrm{~h}$ after birth until wk 8 . An asterisk $(*)$ indicates a significant difference $(P<0.05)$ between CRM and CTR at a given time point. Treatment effect, $P<0.01$; time effect, $P=0.20$; treatment $\times$ time effect, $P=0.33$.

CTR group may show slightly impaired GIT function and calf well-being with Cr supplementation; however, this was not supported by the improved ADG and FCR in CRM calves compared with CTR calves. In addition, despite significant differences between the groups, the health status data in the present study were all in the normal ranges.

In the present study, blood glucose, insulin, and the ratio of insulin to glucose were not influenced by $\mathrm{Cr}$ supplementation. Results are ambiguous concerning the effect of $\mathrm{Cr}$ on glucose and insulin responses in ruminants (Subiyatno et al., 1996; Kegley et al., 2000; Yari et al., 2010; Sadri et al., 2012). Our results are similar to those reported by Yari et al. (2010), who showed that blood concentrations of glucose and insulin were not affected by increasing Cr-Met supplementation during the preweaning period. It appears that the ratio of insulin to glucose may be a better criterion than insulin or glucose alone for evaluating the action of insulin, especially in the glucose tolerance test (Subiyatno et al., 1996). In some previously reported results, during glucose tolerance tests, $\mathrm{Cr}$ supplementation improved insulin efficiency in young calves (Yari et al., 2010) and in transition dairy cows (Hayirli et al., 2001). However, in the current study, the ratio of insulin to glucose was not affected by $\mathrm{Cr}$ supplementation across the experiment.
Subiyatno et al. (1996) reported a tendency for increased circulating IGF-I in response to $\mathrm{Cr}$ supplementation in the propionate loading tests. However, in the present study, blood IGF-I concentrations were not affected by Cr-Met supplementation across the experiment, in agreement with previously reported results in calves (Depew et al., 1998).

Passive transfer of immunity in calves may be assessed directly by measuring serum IgG or serum TP to estimate serum IgG concentration (Wallace et al., 2006). Measuring serum TP has been suggested as a reasonable screening test for estimating the level of passive transfer in calves. In this method, failure of passive transfer is defined as a serum TP concentration of less than $5.2 \mathrm{~g} / \mathrm{dL}$ (Calloway et al., 2002). In the current study, serum TP concentrations within $72 \mathrm{~h}$ after birth showed that the experimental calves in both groups received adequate quantities of colostrum, which was associated with TP concentrations higher than $5.2 \mathrm{~g} /$ $\mathrm{dL}$, and thus probably faced no risk of failure of passive transfer. In addition, we found no statistically significant difference in serum TP levels between the groups over time. This result is in agreement with results of a previous experiment conducted with calves (MoonsieShageer and Mowat, 1993; Yari et al., 2010).

Blood thyroid hormones are considered indicators of the metabolic and nutritional status of the animals. It 
is believed that variations in thyroid hormone bioactivity levels allow the animals to adapt to various environmental and physiological conditions and to variations in nutrient requirements and availability (Todini et al., 2007). To become functional, $T_{4}$ needs to be converted to $\mathrm{T}_{3}$ by a $5^{\prime}$-deiodinase enzyme (Utiger, 1995). In the present study, although blood concentrations of $\mathrm{T}_{3}$ were not affected by treatments over time, Cr-Met supplementation decreased blood $\mathrm{T}_{4}$ at 24 and $72 \mathrm{~h}$ and in wk 4 and 6 , and it increased the blood $\mathrm{T}_{3}: \mathrm{T}_{4}$ ratio at $72 \mathrm{~h}$ and in wk 4 and 6 . It has been suggested that a biological relationship between growth and $\mathrm{T}_{3}$ is more likely than a biological relationship between growth and $\mathrm{T}_{4}$ (Kahl et al., 1977). Therefore, the higher $\mathrm{T}_{3}: \mathrm{T}_{4}$ ratio at $72 \mathrm{~h}$ and in wk 4 and 6 may suggest an improvement in the efficiency of the conversion from $\mathrm{T}_{4}$ to $\mathrm{T}_{3}$ and thereby probably its involvement in the improvement of ADG and final BW with $\mathrm{Cr}$ supplementation.

An interesting finding of the present study was the lower blood BHBA and NEFA concentrations in calves supplemented with Cr. In adult ruminants, BHBA is derived from the incomplete oxidation of FA when energy is limited and the body mobilizes fat. However, in the young calf, the changes in blood BHBA are associated with rumen development. Before the rumen develops, glucose is used as a primary energy source by the calf. When calves are offered a starter concentrate and fermentation occurs, a large amount of BHBA is produced; afterward, the calf is adapted to this new nutrient as a source of energy (Quigley et al., 1991; Klotz and Heitmann, 2006). In the present study, as expected, the increase in BHBA concentrations in both groups over time coincided with the increase in starter intake. The lower concentrations of BHBA at $72 \mathrm{~h}$ and in wk 1, 3, 4, 5, and 6 in calves supplemented with $\mathrm{Cr}$ may reflect the use of peripheral BHBA. Total DMI was not different between the groups; therefore, the lower BHBA in the CRM group than in the CTR group does not seem to be related to reduced rumen wall production and the portal supply of BHBA. On the other hand, blood NEFA concentrations were affected by $\mathrm{Cr}$ supplementation, indicating a more efficient utilization of dietary energy that reduced body fat mobilization. Measured concentrations of BHBA in this study correspond to the higher values for dairy calves up to wk 5 of age reported by Klotz and Heitmann (2006). In the study by Klotz and Heitmann (2006), at 5 wk of age (d 35), the calf starter (dry feed) was offered for ad libitum consumption, and during the adaptation period between wk 5 and 7 , a dramatic increase in BHBA concentration was observed. In contrast, in the current study, calves had ad libitum access to the starter concentrate (dry feed) from d 5 . It therefore seems that the high concentrations of BHBA observed in the current study may be related, at least in part, to earlier initiation of dry feed intake (d 5).

In the present study, calves on the CRM treatment had lower concentrations of cholesterol at all sampling times, except at $12 \mathrm{~h}$ and wk 7 . This is similar to studies involving $\mathrm{Cr}$ supplementation of human subjects, which have demonstrated decreases in concentrations of triacylglycerols and total and low-density lipoprotein cholesterol (Anderson, 1995). On the basis of a novel mechanism of $\mathrm{Cr}$ action, which has been proposed by Chen et al. (2006) and Pattar et al. (2006), Cr activates the glucose transporter 4 trafficking, enhancing insulinstimulated glucose transport in murine adipocytes via a cholesterol-dependent mechanism. In agreement with a reported effect of $\mathrm{Cr}$ on increasing membrane fluidity, they found that $\mathrm{Cr}$ treatment decreased plasma membrane cholesterol, which is consistent with in vivo observations of improved glucose tolerance and decreased circulating cholesterol levels after $\mathrm{Cr}$ supplementation (Chen et al., 2006; Pattar et al., 2006). Whether CrMet acts in the same manner in young calves is unclear; however, the observed decreases in blood cholesterol concentrations in the present study reflect the contribution of this supplement in fat and cholesterol metabolism.

Previous reports have shown that plasma cortisol levels vary with age in normal neonatal calves, with the highest concentration seen during the first days after birth (Lopez and Phillips, 1976). The stressful postnatal period is crucial because the internal defense of the calf is already poor and external stress is severe at this period of life. Therefore, it has been suggested that increased plasma corticoid levels at birth may contribute to a rapid adaptation to conditions of extrauterine life. Another advantage of the higher cortisol during early neonatal life is in GIT development and cell differentiation, particularly in the promotion of digestive enzymes in the pre- and perinatal periods (Sangild, 2001). However, higher levels of cortisol afterward may be disadvantageous, because cortisol may reduce the internal defense through a reduced phagocytic and antibody-producing ability of lymphocytes (Martin and Crump, 2003). In the present study, blood cortisol concentrations did not follow the expected pattern (i.e., did not show significant variation over time; Figure 4), in contrast to previously reports in the literature (Lopez and Phillips, 1976; Sangild, 2001). However, the results of the present study show the beneficial effects of $\mathrm{Cr}$ supplementation to reduce the stress level, as reflected by the lower concentrations of cortisol in supplemented calves at some sampling times. Data on the effects of $\mathrm{Cr}$ on blood concentrations of cortisol in calves have been contradictory (Kegley and Spears, 1995; Depew et al., 1998; Yari et al., 2010). Kegley and Spears (1995) 
reported that $\mathrm{Cr}$ supplementation decreased serum cortisol, but Depew et al. (1998) and Yari et al. (2010) found no effects of $\mathrm{Cr}$ on serum cortisol.

\section{CONCLUSIONS}

Chromium supplementation of colostrum and milk showed greater ADG, improved FCR, and a tendency for increased final BW, with no changes in total DMI in calves. Blood glucose, insulin, the ratio of insulin to glucose, and IGF-I concentrations were not influenced by $\mathrm{Cr}$ supplementation. Declines in blood BHBA and NEFA concentrations along with improved ADG and FCR in calves supplemented with $\mathrm{Cr}$ may reflect an efficient nutrient turnover and a more efficient tissue accretion. Decreases in blood cholesterol concentrations with $\mathrm{Cr}$ may show a contribution of this supplement in fat and cholesterol metabolism. In addition, the results showed the stress-alleviating effects (decreased cortisol) of Cr-Met in dairy calves. Taken together, we suggest that $\mathrm{Cr}$ supplementation of colostrum and milk may be an efficient method for improving the performance and metabolic status of newborn calves.

\section{ACKNOWLEDGMENTS}

The authors express their appreciation to the staff at the calf-raising facilities of Sharifabad Dairy Facilities (SDF, Qazvin, Iran) for diligent animal care; to Eng. M. Morteza Mousavi (SDF), Ali Asadi Alamouti (University of Tehran, Iran), Eng. Javad Yaghoubi, Eng. Mehdi Salimi, and the Khatam Laboratory (Qazvin, Iran), for their help in conducting this experiment; and to Yasna Mehr Company (Tehran, Iran) for partial financial support of this experiment. In addition, appreciation is extended to Jafari Joozani (Veterinary Diagnostic Lab, DPACo., Tabriz, Iran) and Yolande Zbinden (Veterinary Physiology, Vetsuisse Faculty, University of Bern, Switzerland) for their excellent laboratory assistance.

\section{REFERENCES}

Anderson, R. A. 1995. Chromium, glucose tolerance, diabetes and lipid metabolism. J. Adv. Med. 8:37-49.

AOAC International. 2002. Official Methods of Analysis. 16th ed. AOAC International, Arlington, VA.

Blum, J., and H. M. Hammon. 2000. Colostrum effects on the gastrointestinal tract, and on nutritional, endocrine and metabolic parameters in neonatal calves. Livest. Prod. Sci. 66:1151-1159.

Blum, J. W. 2006. Nutritional physiology of neonatal calves. J. Anim. Physiol. Anim. Nutr. (Berl.) 90:1-11.

Bunting, L. D., T. A. Tarifa, B. T. Crochet, J. M. Fernandez, C. L. Depew, and J. C. Lovejoy. 2000. Effects of dietary inclusion of chromium propionate and calcium propionate on glucose disposal and gastrointestinal development in dairy calves. J. Dairy Sci. 83:2491-2498.

Calloway, C. D., J. W. Tyler, R. K. Tessman, and D. Hostetler. 2002. Comparison of refractometers and test endpoints in the measure- ment of serum protein concentration to assess passive transfer status in calves. J. Am. Vet. Med. Assoc. 221:1605-1608.

Chen, G., P. Liu, R. G. Pattar, L. Tackett, P. Bhonagiri, A. B. Strawbridge, and J. S. Elmendorf. 2006. Chromium activates glucose transporter 4 trafficking and enhances insulin-stimulated glucose transport in 3T3-L1 adipocytes via a cholesterol-dependent mechanism. Mol. Endocrinol. 20:857-870.

Davis, C. M., A. C. Royer, and J. B. Vincent. 1997. Synthetic multinuclear chromium assembly activates insulin receptor kinase activity: Functional model for low-molecular-weight chromium-binding substance. Inorg. Chem. 36:5316-5320.

Davis, C. M., and J. B. Vincent. 1997. Chromium oligopeptide activates insulin receptor tyrosine kinase activity. Biochemistry 36:4382-4385.

Depew, C. L., L. D. Bunting, J. M. Fernandez, D. L. Thompson Jr., and R. W. Adkinson. 1998. Performance and metabolic responses of young dairy calves fed diets supplemented with chromium tripicolinate. J. Dairy Sci. 81:2916-2923.

Hayirli, A., D. R. Bremmer, S. J. Bertics, M. T. Socha, and R. R. Grummer. 2001. Effect of chromium supplementation on production and metabolic parameters in periparturient dairy cows. J. Dairy Sci. 84:1218-1230.

Heldin, C. H. 1995. Dimerization of cell surface receptors in signal transduction. Cell 80:213-223.

Kahl, S., T. R. Wrenn, and J. Bitman. 1977. Plasma tri-iodothyronine and thyroxine in young growing calves. J. Endocrinol. 73:397-398.

Kegley, E. B., D. L. Galloway, and T. M. Fakler. 2000. Effect of dietary chromium-L-methionine on glucose metabolism of beef steers. J. Anim. Sci. 78:3177-3183.

Kegley, E. B., and J. W. Spears. 1995. Immune response, glucose metabolism, and performance of stressed feeder calves fed inorganic or organic chromium. J. Anim. Sci. 73:2721-2726.

Kegley, E. B., J. W. Spears, and J. H. Eisemann. 1997. Performance and glucose metabolism in calves fed a chromium-nicotinic acid complex or chromium chloride. J. Dairy Sci. 80:1744-1750.

Klotz, J. L., and R. N. Heitmann. 2006. Effects of weaning and ionophore supplementation on selected blood metabolites and growth in dairy calves. J. Dairy Sci. 89:3587-3598.

Kumpulainen, J., E. Vuori, S. Makinen, and R. Kara. 1980. Dietary chromium intake of lactating Finnish mothers: Effect on the $\mathrm{Cr}$ content of their breast milk. Br. J. Nutr. 44:257-263.

Larson, L. L., F. G. Owen, J. L. Albright, R. D. Appleman, R. C. Lamb, and L. D. Muller. 1977. Guidelines toward more uniformity in measuring and reporting calf experimental data. J. Dairy Sci. 60:989-991.

Lloyd, K. E., V. Fellner, S. J. McLeod, R. S. Fry, K. Krafka, A. Lamptey, and J. W. Spears. 2010. Effects of supplementing dairy cows with chromium propionate on milk and tissue chromium concentrations. J. Dairy Sci. 93:4774-4780.

Lopez, G. A., and R. W. Phillips. 1976. Plasma corticoid levels during early postnatal life in calves. Proc. Soc. Exp. Biol. Med. 151:415417.

Martin, P. A., and M. H. Crump. 2003. The adrenal gland. Pages 165-200 in McDonald's Veterinary Endocrinology. M. H. Pineda, ed. Iowa State University Press, Ames.

Mathison, G. W., and D. F. Engstrom. 1995. Chromium and protein supplements for growing-finishing beef steers fed barley-based diets. Can. J. Anim. Sci. 75:549-558.

Moonsie-Shageer, S., and D. N. Mowat. 1993. Effect of level of supplemental chromium on performance, serum constituents and immune status of stress feeder calves. J. Anim. Sci. 71:232-238.

Mowat, D. N., X. Chang, and W. Z. Yang. 1993. Chelated chromium for stressed feeder calves. Can. J. Anim. Sci. 73:49-55.

NRC. 2001. Nutrient Requirements of Dairy Cattle. 7th rev. ed. Natl. Acad. Sci., Washington, DC.

Pattar, G. R., L. Tackett, P. Liu, and J. S. Elmendorf. 2006. Chromium picolinate positively influences the glucose transporter system via affecting cholesterol homeostasis in adipocytes cultured under hyperglycemic diabetic conditions. Mutat. Res. 610:93-100.

Penchev Georgiev, I. 2008. Differences in chemical composition between cow colostrum and milk. Bulg. J. Vet. Med. 11:3-12. 
Quigley, J. D., L. A. Caldwell, G. D. Sinks, and R. N. Heitmann. 1991. Changes in blood glucose, non-esterified fatty acids, and ketones in response to weaning and feed intake in young calves. J. Dairy Sci. 74:250-257.

Sadri, H., G. R. Ghorbani, H. R. Rahmani, A. H. Samie, M. Khorvash, and R. M. Bruckmaier. 2009. Chromium supplementation and substitution of barley grain with corn: Effects on performance and lactation in periparturient dairy cows. J. Dairy Sci. 92:5411-5418.

Sadri, H., H. R. Rahmani, M. Khorvash, G. R. Ghorbani, and R. M. Bruckmaier. 2012. Chromium supplementation and substitution of barley grain with corn: Effects on metabolite and hormonal responses in periparturient dairy cows. J. Anim. Physiol. Anim. Nutr. (Berl.) 96:220-227.

Sangild, P. T. 2001. Transitions in the life of the gut and brain. Pages 3-17 in Digestive Physiology of Pigs. J. E. Lindberg and B. Ogle, ed. CABI Publishing, Wallingford, UK.

SAS Institute. 2003. SAS User's Guide. Version 9.1. SAS Inst. Inc., Cary, NC.

Smith, K. L., M. R. Waldron, J. K. Drackley, M. T. Socha, and T. R. Overton. 2005. Performance of dairy cows as affected by prepartum dietary carbohydrate source and supplementation with chromium throughout the transition period. J. Dairy Sci. 88:255-263.

Subiyatno, A., D. N. Mowat, and W. Z. Yang. 1996. Metabolite and hormonal responses to glucose or propionate infusions in periparturient dairy cows supplemented with chromium. J. Dairy Sci. 79:1436-1445.
Swanson, K. C., D. L. Harmon, K. A. Jacques, B. T. Larson, C. J. Richards, D. W. Bohnert, and S. J. Paton. 2000. Efficacy of chromium-yeast supplementation for growing beef steers. Anim. Feed Sci. Technol. 86:95-105.

Todini, L., A. Malfatti, A. Valbonesi, M. Trabalza-Marinucci, and A. Debenedetti. 2007. Plasma total $\mathrm{T}_{3}$ and $\mathrm{T}_{4}$ concentrations in goats at different physiological stages, as affected by the energy intake. Small Rumin. Res. 68:285-290.

Utiger, R. D. 1995. The thyroid: Physiology, thyrotoxicosis, hypothyroidism, and the painful thyroid. Pages 435-519 in Endocrinology and Metabolism. 3rd ed. P. Felig, J. D. Baxter, and L. A. Frohman, ed. McGraw-Hill Inc., New York, NY.

Vicari, T., J. J. G. C. van den Borne, W. J. J. Gerrits, Y. Zbinden, and J. W. Blum. 2008. Postprandial blood hormone and metabolite concentrations influenced by feeding frequency and feeding level in veal calves. Domest. Anim. Endocrinol. 34:74-88.

Wallace, M. M., B. D. Jarvie, N. R. Perkins, and K. E. Leslie. 2006. A comparison of serum harvesting methods and type of refractometer for determining total solids to estimate failure of passive transfer in calves. Can. Vet. J. 47:573-575.

Yari, M., A. Nikkhah, M. Alikhani, M. Khorvash, H. Rahmani, and G. R. Ghorbani. 2010. Physiological calf responses to increased chromium supply in summer. J. Dairy Sci. 93:4111-4120. 